Petrovska O. V., Starenkyi R. M. Integration of the capabilities of individual territorial communities and the network form of training for the implementation of project educational trajectories

Nowadays the major problem of education is to find new ways for knowledge acquisition, transformation of teaching methods, and update of educators' methodological base. The rapid increase of the information volumes, technological development of society, constant necessity to update the structure and content of the individual thinking process are decisive factors, when it comes to the necessity to educate an individual with a high level of adaptation. It is difficult to underestimate the impact of effective education and training system on the development of the state that is why all the countries in the world face a problem to search for a modern educational paradigm. The article deals with the substantial analysis of the recent changes to the Ukrainian education system towards the modernization of children secondary education. Also the article suggests an optional way to integrate the educational process in a comprehensive educational institution into the social, cultural and administrative life of the community through the implementation of project educational trajectories. The development of different communication levels between the participants in the educational process plays a significant role in modernization and shaping the value aspect in understanding of cultural globalization trends. The article substantiates the effectiveness of communication between students of different countries, regardless of gender, age and cultural or social life conditions.

Based on the analysis of normative documentation, literary sources and scientific articles on pedagogy, and also guided by the results of personal managerial and pedagogical experience, the authors substantiate the importance of educational complexes' creation by introduction of a network form of training in the conditions of newly created separate territorial communities to enable the development of educational methods for building educational trajectories for schoolchildren. As a result of the practical testing of the scientific assumption, a considerable progress has been made in the formation of modern communicative, digital, linguistic, social and social competences among schoolchildren.

Key words: separate territorial community, network form of training, educational complex, personal educational trajectories, socialization, project activity, personalization of learning.

УДК 37.01

DOI https://doi.org/10.31392/NPU-nc.series5.2020.74.24

Polishchuk H. $V$.

\title{
THE IMPACT OF EUROPEAN INTEGRATION OF UKRAINE IN EDUCATIONAL SPHERE ON PROFESSIONAL PREPARATION OF FUTURE FOREING LANGUAGE TEACHERS' CONFLICTOLOGICAL COMPETENCE
}

The paper deals with the definition of the notion "professional preparation of future foreign language teachers" and its constituents (linguistic, psychological-pedagogical and methodical) in the aspect of contemporary European integration of Ukraine. It has been estimated that the notion "readiness for professional activity" is included into the notion "preparation" due to the necessity to point out the result expected from the preparation of the students. Professional preparation of future teachers as a complex pedagogical system is viewed as a whole organization based on connections and interdependence of its components. It has been emphasized that the reform tendencies in professional preparation of foreign language teachers in well-known European countries have to do with the content, forms and methods of teaching; are connected with informatization and technologization of educational sphere, and are characterized by having a link between high and secondary educational establishments. The following three levels in the conflictological preparation of the teachers of foreign language are singled out: theoretical (the formation of interdisciplinary knowledge about the conflict, life values and orientations, moral norms and principles), theoretical applied (skills of using famous strategies and tactics of conflict resolution and formation of skills of handling conflicts in collaborative way), practical (the formation of individual strategy of behavior in conflict situation; the ability to predict and analyze real conflicts). Modern contexts of conflictological preparation of future foreign language teachers have been estimated and analyzed: cross-cultural, communicative and interpersonal. The author's interpretation of the notion "conflictological competence of future foreign language teachers" has been given.

Key words: European integration, professional preparation, readiness for professional activity, conflictological preparation, conflictological competence of future foreign language teachers.

Introduction. Reforms in the system of high education connected with the adoption of such important normative documents as National Strategy of Education development of Ukraine till 2021 (2013), The law of high education (2014), The law of education (2017) presuppose concrete changes in preparation of future teachers and their professional growth. The main aim of modern Ukrainian system of education is the creation of conditions of development and self-realization of a personality in high educational establishments, formation of their basic competences that will help to solve different problems in the future professional activity. Conflictological competence is the part of key competences that is why its development is the priority in the professional growth of future teachers. Thus, the purpose of the study is to systematize the current innovational strategies of education implemented into professional preparation of future foreign language teachers' conflictological competence under the influence of European integration of Ukraine. 
The analysis of recent research and publications. Implementation of new system of education requires innovational changes in the process of preparation of the future teachers of foreign languages. First, it is concerned with the content and structure of preparation, implementation in practice of new innovational methods and strategies of education, modern pedagogical technologies etc. Second, European Profile for Language Teacher Education (2004) stresses the following professional competences that must be acquired by foreign language teachers: modern informational and communicative technologies; the knowledge of the main principles of the methods of foreign language teaching and the ability to adapt them to concrete circumstances and forms of education; the ability to analyze educational resource materials from the point of the aim, tasks and results of education; the ability to adapt personal educational acts to local national and cultural requirements, also methodological traditions; support of regular contacts with representatives of those countries the language is studied and organization of such contacts in educational aim [16]. Thus, foreign language teacher has to be IKT-competent, knowledgeable from the point of view of methods of teaching and able to self-growth, self-development and self-realization, and have contacts with the representatives of other countries.

Under the circumstances of Euro integration in the system of education the prestige of getting the qualification of the teacher of foreign languages is constantly increasing, as well as the necessity of the knowledge of foreign languages. As the result the attitude of youth towards learning foreign language as secondary subject changes, the necessity in high-level professionals is growing having B2, B1, C1 and C2 levels in foreign languages. It is important to underline that in 2022 in Ukraine foreign languages are planned to be fixed as obligatory subject for entering high educational establishments. The main emphasis in Ukraine is also laid on the necessity of increasing the level of teaching of foreign languages at schools due to several reasons: foreign language is an effective factor of the humanization of education as its usage is connected with the process of communication directed at handling interpersonal relationships; it is also regarded not only as means of humanization that exerts influence on the development of personality, but as a part of his professional growth; the knowledge of foreign language helps to develop mentality; foreign languages acquisition develops logical thinking of a person; foreign languages learning helps to develop cross-cultural communication of a person. It must be also underlined that due to foreign language acquisition students are able to master the art and culture of the country, the creative heritage of its writers and poets, the customs, traditions and wisdom of the nation that broadens their outlook. Future foreign language teacher is also able to enrich his knowledge through written communication: translations of scientific articles, report writing, making annotations etc.; to get important information about the development of his professional sphere abroad and compare his own achievements with the achievements of his colleagues abroad; to take part in different scientific and technological conferences to up his results to the world's standards. It is out of the question that future foreign language teacher should be capable of reading and translating special literature, investigating and systematizing materials about professional activity that helps to provide business dialogues, business correspondence etc. All above-mentioned statements stress that foreign language students gradually develop the ability to work with foreign professional information and to choose the most rational and useful methods of foreign language acquisition [4, c. 39-40]. Thus, foreign language is not only the way of global communication; it is also fresh opportunity as for the humanization of education and the way of creating interpersonal relationships between people of different nationalities.

However, on the contemporary stage of the development of education in Ukraine foreign languages are not given an adequate treatment: in the majority of cases only the English language is studied, less hours of German are suggested, and only some hours of French or Spanish. The cases of Chinese, Polish, Japanese or Hungarian at Ukrainian schools are very rare. In addition, it must be pointed out that only one foreign language has been studied in the majority of schools up to the present moment [3, c. 87].

The problem of preparation of foreign language teachers in Ukrainian high educational establishments is drawn attention to by T.Bocharnikova. The author claims that future foreign language teachers in Ukraine are prepared in three types of high educational establishments: foreign language departments of pedagogical universities; foreign language departments of classical universities; departments of pedagogical colleges. The author stresses that such spectrum of foreign language teachers' preparation is not always able to guarantee the necessary level of professional knowledge for the work at contemporary schools [1, c. 22]. In summary, at the contemporary stage of the development of Ukrainian system of high education one can witness the problem of improvement of the choice of talented young people with the aim of gaining qualification of the teacher of foreign languages and the modernization of their professional preparation in the higher educational establishments.

Theoretical background. Different aspects of the professional preparation of future teachers have been in the focus of many research studies in the field of conflictology (N. Dem'yanenko, L. Polishchuk, O. Pechota, V. Budak, A. Stareva, I. Sadova and others.). In the focus of our research, the following findings are relevant and important devoted to the preparation of the teachers of foreign languages are found in the works of V. Bezlyudna, N. Brahznik, I. Bogdanova, V. Gamanyuk, R. Martunova, S. Nikolaeva, O. Petrashchuk and others.

Now let us analyze the notion professional preparation and its constituents. There are different approaches to the notion in pedagogical research papers as is claimed by I. Sadova: when it is treated as the synonym to professional activity (N,Kostina), or the term has been included to the definition (L. Grigorenko, T. Gushchina, G. Trotsko), or the accent has been made on the essence, forms and methods of professional preparation, the result of preparation as 
the enumeration of skills and knowledge that the future professional has to gain (V. Zhyravlev, S. Kiselgof, N. Kuzmina); the unity with the process of formation of professional qualities of the teacher, the investigation of the ways of the development of the pedagogical aptitudes of the teacher (F. Gonoblin, L. Kondrashova) etc. [13, c. 81].

Numerous scientific works of contemporary researchers agree that the notion of professional preparation of teachers is a system based on homogeneous whole where all elements are united by educational aim of the development of the personality and his professionally important personal qualities. The introduction of the notion "readiness for the professional activity" to the definition of the notion "readiness" is determined by the necessity to point out the result that is expected from the preparation of the students. Therefore, the professional preparation of future teachers turns out to display united internal organization based on the interdependence of its components in the pedagogical system as a whole [12, c. 117].

The following constituents in the professional preparation of the teachers of foreign language are singled out by S. Nikolaeva, O. Petrashchuk and others: theoretical linguistic and practical language preparation (the supply of knowledge of the theory and history of a foreign language; the development of intellectual potential of the students and their analytical thinking); theoretical and practical psychological pedagogical preparation (knowledge of the theory of pedagogy, theoretical background as for the organization of educational process in different types of secondary education establishments; the formation of important skills of conducting pedagogical investigation); theory and practice of methods (conducting foreign language lessons and out of class activities in foreign language, professional pedagogical improvement by self-education or at the special courses) [10, c. 9-17]. Concluding the above said professional preparation of future foreign language teachers is divided into theoretical and practical and has three main parts - linguistic, psychologo-pedagogical and methods.

Now we can generalize the following in the form of definition: professional preparation of future teacher of foreign language can be defined as homogeneous pedagogical system oriented on personal and professional development of the students in the process of linguistic, psychological, methodological and pedagogical preparation that helps to create readiness for their professional activity.

Professional preparation of future teachers of foreign language is not a static phenomenon; it needs constant changes and modernization taking into consideration the demands of the society, the economic situation in the country and modern reform tendencies. The main modern reform tendencies in the professional preparation of the teachers of foreign languages in European countries are summarized by O. Marheva: the orientation of the content of education on the result, the modernization of the forms of its organization, strengthening of professional scientific preparation and shift of its accents on the formation of cross-cultural, country study and integral methods competences; to provide the correspondence of forms and methods of organization of the process of education in higher educational establishments to schools; informatization and technologization of the process of education and increase the importance of self-study of the students [9, c. 9-10]. As we see the tendencies of reformation of professional preparation of the teachers of foreign language in the leading European countries are mainly connected with the changes in the content, forms and methods of education and are concerned with informatization and technologization of educational sphere and links of high and secondary education.

We absolutely agree with T.Kolodko that inevitable changes in the content of higher education are the basis for the formation of the new generation teacher presupposing fundamentalization, humanitarization and differentiation, and also the development and realization of innovative technologies. The author underlines that the most important thing is to make an accent on the necessity of changes in the character of future preparation of the teachers of foreign language, in its general pedagogical and foreign language preparation as its aim is to develop students' professional thinking, formation of professional skills and ability to work at school [7, c. 195-197].

Within the scope of pedagogy, there is a lack of scientific investigations of definite aspects of professional preparation of future teachers of foreign languages as pointed out by Mayer, especially in the context of defining its peculiarities as for conflict competence [8, c. 19]. The overview of existing approaches to the study of conflicts showed that the process of complex research of conflict preparation of future teachers has not been finished yet. Further investigation should take into consideration the following topics: the formation of the system of conflict competence knowledge and skills, the theory and practice of conflict resolution strategies, the formation of personal pedagogical position, and analysis of modern strategies of successful conflict management.

In the light of the said above conflictological preparation in the system of higher education has to be conducted on three levels: theoretical, theoretical applied, practical. Theoretical level includes theoretical akmeological knowledge which is considered to be theoretical mode of conflict management. General theoretical knowledge is studied at this level as well as life values, moral norms and principles that are important for students in their professional activity. Theoretical applied level can be characterized as the system of theoretical applied akmeological knowledge, defining practical orientation and motivation of the future professional activity in conflict management. Students are able to reach this level due to lecture attendance, business games, trainings, group discussions of conflict situations. Practical level of conflictological preparation helps students to acquire practical akmeological knowledge which appears and functions in the real process of professional activity. This level presupposes the formation of personal experience in conflict management, style of communication in conflict situations, formation of personal strategy of behavior in conflict situation and the ability to foresee and analyze real conflicts while solving practi- 
cal tasks [14, c. 15-16]. The author characterized the levels of conflictological preparation of managers but in our opinion, these levels can adequately be applied to conflictological preparation of future teachers of foreign language taking into consideration the peculiarities of their qualification.

After having analyzed different types of conflicts, O.Shcherbakova differentiates specific contexts of their flow: cross-cultural, interpersonal, space temporal, gender, communicative and age that is important to take into consideration in preparation of future teachers $[15$, c. 51$]$. We are of the same point of view that above-mentioned aspects are specific for conflictological preparation in general and for future teachers in particular. We consider that the main contexts of conflictological preparation of future teachers of foreign language are cross-cultural, communicative and interpersonal.

Following O. Demyanenko [5, c.170-171], cross-cultural context of conflictological preparation of future teachers of the foreign languages lies in the knowledge of the students as for the following: cultural discrepancies between people of different nations, the ability to express one's thoughts and feeling as for these discrepancies; the ability to find common ground with representatives of different cultures, outlooks, religions; the choice of relevant modes of behavior in certain situations; skills of evaluating personal experience in conflict situations and its usage in future professional activity.

Now communicative context of conflictological preparation of future teachers of foreign languages must be dwelt upon. Contemporary communication is viewed as social process of exchanging different information that is transmitted with the help of language resources having an aim of achieving understanding between the partners/ speakers according to definite rules and norms of communication.

In the process of professional preparation of future teachers of foreign languages special attention is given to foreign language acquisition, which includes not only the volume, structure and content of educational material, but also communication ability in the foreign language taking into consideration the emotional state of the students, their personal peculiarities, and their attitude to the subject etc. Foreign language communication of future teachers takes place at practical classes and seminars in the higher educational establishments. Foreign language preparation of future teachers is not only teaching students of stereotyped language clichés, it should stimulate further improvement of interpersonal communication and modern language tactics helping to form personal strategies of behavior in the process of communication.

There are the following definitions of speech strategy and communicative strategy in present day scientific literature: as total of planned before theoretical steps, which are realized in communicative act and directed to achieve communicative aims [6, c. 18]; the term speech tactics is viewed as total of practical steps in real process of communication [6, c. 19].

Foreign language acquisition in the process of foreign language preparation of future teachers gives the basis for their competence. «The European Indicator of Language Competence» examines foreign language competence as integration of three main subtypes: linguistic competence (a system of knowledge of the language used in communication); social competence (having sociocultural, sociolinguistic and professional components that help to realize the main aim of modern education when foreign language is understood as means of sociocultural development of personality); communicative competence (knowledge of general grammar rules giving the ability to use the language in the process of communication) [17].

O. Nikolaeva stresses important components of foreign language preparation of future teachers: formation of speech competence including reading, writing, speaking, audition and translation; language competence including the knowledge of language material; linquosociocultural competence including sociolinguistic, sociocultural and social competence $[11, \mathrm{c.}$ 12]. Thus, native and foreign scientists agree that the structure of foreign language competence includes linguistic, social and communicative components.

Interpersonal context of conflictological preparation of future teacher of foreign languages is closely connected with the above-mentioned contexts. But it should be noted that all these cannot be limited by competence approach as it presupposes the development of conflictological culture of a person oriented on constant self-development and improvement of the cultural sphere of a person. We fully agree with T. Branitska that the content of conflictological preparation is a part of professional education aiming to develop conflictological culture based on knowledge integration of theory and practice [2, c. 21]. Cultural aspect of professional preparation of future teachers of foreign languages is extremely important as these teachers have to acquire cultural inheritance of different countries of the world, to realize and acquire all human values that open the way to understanding and tolerant attitude to other nationalities.

Conclusions and perspectives. Fruitful analyses of contemporary scientific literature on the problem of our investigation gives the opportunity to generalize on the following peculiarities of conflictological preparation of future teachers of foreign languages under the influence of European integration of Ukraine:

1. Conflictological preparation of future teachers has theoretical (formation of interdisciplinary knowledge about conflicts, life values, moral norms and principles), theoretical applied (the usage of conflict resolution strategies and tactics) and practical (formation of individual strategy of behavior in conflict).

2. The main contexts of conflictological preparation of future teachers are cross-cultural, communicative and interpersonal. 
Examination of the huge material on peculiarities of professional preparation of future teachers of foreign languages in the aspect of the formation of their conflilctological competence gives the opportunity to summarize the most important features of this phenomenon. So in our research paper we consider conflictological competence of future teachers of foreign languages to be an integral personal formation based on the system of scientific knowledge about the conflict, skills and practical experience of conflict resolution that are developed in cross-cultural, communicative and interpersonal contexts of conflictological preparation in higher educational establishments.

\section{Bibliography:}

1. Бочарникова Т. Ф. Особливості професійно-педагогічної спрямованості майбутніх учителів іноземних мов. Проблеми інженерно-педагогічної освіти. 2012. № 36. С. 21-25.

2. Браніцька Т. Р. Спецкурс «Основи конфліктологічної культури» та його роль у формуванні конфліктологічної культури майбутніх фахівців соціономічних професій сфери. Scientific Journal «ScienceRise: Pedagogical Education». 2017. № 1(9). C. 20-23.

3. Гаманюк В. А. Підготовка вчителів іноземних мов на тлі тенденцій до багатомовної освіти. Науковий вісник Національного університету біоресурсів і природокористування України. Сер.: Педагогіка, психологія, філософія. 2014. Вип199(1).C.86-91. URL: http://nbuv.gov.ua/UJRN/nvnau ped 2014 199\%281\%29 14.

4. Демченко Д. І. Формування професійної іншомовної компетентності майбутніх юристів засобами іноземної мови у фаховій підготовці : монографія. Харків : Видавець Іванченко І. С., 2014. 213 с.

5. Дем'яненко О. Формування кроскультурної компетентності майбутніх учителів іноземної мови. Проблеми підготовки сучасного вчителя. 2012. № 6 (Ч. 1). С. 167-172.

6. Клюев Е. В. Речевая коммуникация: учеб. пособие для университетов и вузов. Москва: ПРИОР, 2002.210 с.

7. Колодько Т. Педагогічний аспект фахової підготовки майбутніх учителів іноземних мов у контексті європейського освітнього простору. Освіта дорослих: теорія, досвід, перспективи. 2014. Вип. 1 (8). С. 190-199.

8. Майєр Н. В. Вимоги до сучасного викладача іноземних мов вищого навчального закладу. Іноземні мови. 2013. № 3. С. $19-24$.

9. Мархева О. Є. Стандартизація професійної підготовки вчителів іноземних мов в умовах Болонського процесу: автореф. дис. ... канд. пед. наук: 13.00.04 /Національний авіаційний ун-т. Київ, 2015. 22 с.

10. Ніколаєва С. Ю. Петращук О. П., Бражник Н. О. Ступенева система освіти в Україні та система навчання іноземних мов. Київ: Ленвіт, 1996. 89 с.

11. Ніколаєва С. Ю. Цілі навчання іноземних мов в аспекті компетентнісного підходу. Іноземні мови. 2010. № 2. С. 11-17.

12. Поліщук Л. П. Особливості професійної підготовки майбутніх фахівців у педагогічних закладах України. Вісник Житомирського державного університету імені Івана Франка. 2009. Вип. 48. С. 112-119.

13. Садова І. Проблеми удосконалення професійної підготовки майбутнього вчителя у педагогічній теорії. Молодь $i$ ринок. 2012. № 1 (84). С. 80-84.

14. Серебровская Н. Е. Конфликтологическая подготовка будущих специалистов по управлению: актуальне проблемы и задачи. Психопедагогика в правоохранительных органах. 2010. № 2(41). С. 15-22

15. Щербакова О. И. Конфликтологическая подготовка специалиста: контекстный поход. Психологическая наука и образование. 2009. № 1. С. 48-54.

16. European Profile for Language Teacher Education - A Frame of Reference: A Report to the European Commission Directorate General for Education and Culture / Written by Michael Kelly, Michael Grenfell, Rebecca Allan, Christine Kriza and William McEvoy. University of Southampton, 2004. 124 p. URL: http://ec.europa.eu/languages/documents/ doc477_en.pdf.

17. The European Indicator of Language Competence. Report from the Educational Council to the European Council. Barcelona, March 2002. URL : http://www.edu.language learning.com.ua.

\section{References:}

1. Bocharnykova T.F. Osoblyvosti profesiyno-pedahohichnoyi spryamovanosti maybutnikh uchyteliv inozemnykh mov. Problemy inzhenerno-pedahohichnoyi osvity. 2012. \# 36. S. 21-25.

2. Branits'ka T. R. Spetskurs «Osnovy konfliktolohichnoyi kul'tury» ta yoho rol' u formuvanni konfliktolohichnoyi kul'tury maybutnikh fakhivtsiv sotsionomichnykh profesiy sfery. Scientific Journal «ScienceRise: Pedagogical Education». 2017. \# 1(9). S. $20-23$.

3. Hamanyuk V. A. Pidhotovka vchyteliv inozemnykh mov na tli tendentsiy do bahatomovnoyi osvity. Naukovyy visnyk Natsional'noho universytetu bioresursiv i pryrodokorystuvannya Ukrayiny. Ser.: Pedahohika, psykholohiya, filosofiya. 2014. Vyp. 199 (1). S. 86-91. URL: http://nbuv.gov.ua/UJRN/nvnau_ped_2014_199\%281\%29_14.

4. Demchenko D. I. Formuvannya profesiynoyi inshomovnoyi kompetentnosti maybutnikh yurystiv zasobamy inozemnoyi movy u fakhoviy pidhotovtsi : monohrafiya. Kharkiv : Vydavets' Ivanchenko I. S., 2014. 213 s.

5. Dem"yanenko O. Formuvannya kroskul'turnoyi kompetentnosti maybutnikh uchyteliv inozemnoyi movy. Problemy pidhotovky suchasnoho vchytelya. 2012. \# 6 (Ch. 1). S. 167-172.

6. Klyuev E. V. Rechevaya kommunykatsyya: ucheb. posobye dlya unyversytetov y vuzov. Moskva: PRYOR, $2002.210 \mathrm{~s}$.

7. Kolod'ko T. Pedahohichnyy aspekt fakhovoyi pidhotovky maybutnikh uchyteliv inozemnykh mov u konteksti yevropeys'koho osvitn'oho prostoru. Osvita doroslykh: teoriya, dosvid, perspektyvy. 2014. Vyp. 1 (8). S. 190-199.

8. Mayyer N. V. Vymohy do suchasnoho vykladacha inozemnykh mov vyshchoho navchal'noho zakladu. Inozemni movy. 2013. \# 3. S. 19-24.

9. Markheva O. Ye. Standartyzatsiya profesiynoyi pidhotovky vchyteliv inozemnykh mov v umovakh Bolons'koho protsesu: avtoref. dys. ... kand. ped. nauk: 13.00.04 / Natsional'nyy aviatsiynyy un-t. Kyyiv, 2015. $22 \mathrm{~s}$.

10. Nikolayeva S. Yu. Petrashchuk O. P., Brazhnyk N. O. Stupeneva systema osvity v Ukrayini ta systema navchannya inozemnykh mov. Kyyiv: Lenvit, 1996. 89 s.

11. Nikolayeva S. Yu. Tsili navchannya inozemnykh mov v aspekti kompetentnisnoho pidkhodu. Inozemni movy. 2010. \# 2. S. 11-17.

12. Polishchuk L. P. Osoblyvosti profesiynoyi pidhotovky maybutnikh fakhivtsiv u pedahohichnykh zakladakh Ukrayiny. Visnyk Zhytomyrs'koho derzhavnoho universytetu imeni Ivana Franka. 2009. Vyp. 48. S. 112-119.

13. Sadova I. Problemy udoskonalennya profesiynoyi pidhotovky maybutn'oho vchytelya u pedahohichniy teoriyi. Molod' i rynok. 2012. \#1 (84). S. 80-84. 
14. Serebrovskaya N. E. Konflyktolohycheskaya podhotovka budushchykh spetsyalystov po upravlenyyu: aktual'ne problemы y zadachy. Psykhopedahohyka v pravookhranytel'nukh orhanakh. 2010. \# 2(41). S. 15-22.

15. Shcherbakova O. Y. Konflyktolohycheskaya podhotovka spetsyalysta: kontekstnoy pokhod. Psykholohycheskaya nauka y obrazovanye. 2009. \# 1. S. 48-54.

16. European Profile for Language Teacher Education - A Frame of Reference: A Report to the European Commission Directorate General for Education and Culture / Written by Michael Kelly, Michael Grenfell, Rebecca Allan, Christine Kriza and William McEvoy. University of Southampton, 2004. 124 r. URL: http://ec.europa.eu/languages/documents/ doc477_en.pdf.

17. The European Indicator of Language Competence. Report from the Educational Council to the European Council. Barcelona, March 2002. URL: http://www.edu.language learning.com.ua.

Поліщук Г. В. Вплив Свроінтеграційного руху Украӥни у сфері вищої освіти на професійну підготовку майбутніх учителів іноземної мови в аспекті формування конфліктологічної компетентності.

У статті автором визначено сутність поняття «професійна підготовка майбутніх учителів іноземних мов» та ї̈ складових (лінгвістичної, психолого-педагогічної та методичної) в аспекті сучасного Євроінтеграційного руху України. Доведено, шьо внесення поняття «готовність до професійної діяльності» до визначення поняття «підготовка» детерміновано необхідністю вказати на результат, який очікується внаслідок підготовки студентів. Як складна педагогічна система, професійна підготовка майбутніх вчителів виявляє єдину внутрішню організацію на основі зв'язків і залежностей між ї̈ компонентами. 3'ясовано, шьо тендениії реформування професійної підготовки вчителів іноземних мов у провідних європейських державах стосуються змін у змісті, формах $і$ методах навчання; пов'язані з інформатизацією та технологізацією освітньої галузі, зв 'язком закладів вищої освіти і школи. Розглянуто конфліктологічну підготовку в системі вищої освіти на трьох рівнях: теоретичному (формування міждисциплінарних знань про конфлікт, світоглядних орієнтацій, життєвих иінностей, моральних норм і принципів); теоретико-прикладному (управляння у застосуванні відомих стратегій і тактик розв'язання конфліктів, формування навичок щодо попередження деструктивного розвитку конфлікту); практичному (формування індивідуальної стратегї поведінки в конфлікті, спроможність прогнозувати й аналізувати реальні конфлікти). Визначено та охарактеризовано сучасні контексти конфліктологічної підготовки майбутніх учителів іноземних мов (кроскультурний, комунікативний $і$ внутрішньоособистісний). Подано авторське тлумачення поняття «конфліктологічна компетентність майбутніх учителів іноземних мов».

Ключові слова: Євроінтеграція, професійна підготовка, готовність до професійної діяльності, конфліктологічна підготовка, конфліктологічна компетентність майбутніх учителів іноземних мов.

\author{
УДК 372.879.6 \\ DOI https://doi.org/10.31392/NPU-nc.series5.2020.74.25
}

Полулященко Т. Л.

\title{
ПЕДАГОГІЧНІ ОСОБЛИВОСТІ МЕТОДИЧНОГО ЗАБЕЗПЕЧЕННЯ ФІЗИЧНОГО ВИХОВАННЯ У НАВЧАЛЬНИХ ЗАКЛАДАХ ОСВІТИ
}

У статті розглядаються актуальні питання формування у здобувачів освіти активного інтересу до систематичних занять фізичними вправами, до оволодіння вміннями та навиками використання вправ у повсякденному житті за иілеспрямованої співпраці методичної та наукової груп загальноосвітнього навчального закладу з навчально-науковим інститутом фізичного виховання і спорту. Розглянуто педагогічні особливості методичного забезпечення процесу фізичного виховання у навчальних закладах освіти м. Кремінна. Розкрито сутність використання педагогічних методів із метою активізачї інтересу здобувачів освіти до регулярних самостійних занять фізичними вправами. Важливим, на думку фахівиів, є використання викладачами, тренерами стимулів, таких як похвала, подяка, особистий приклад тощо. 3'ясовано роль методистів, викладачів і всіх учасників виховного процесу у сприянні розвитку активного інтересу до занять фізичними вправами. Основною метою статті є дослідити педагогічні особливості забезпечення фізичного виховання в навчальних закладах в умовах реформування всієї освіти. Охарактеризовано матеріально-технічну, спортивну базу м. Кремінна та навчальних освітніх закладів базової та вищої школи. За допомогою використання таких методів дослідження, як аналіз та узагальнення науково-методичної літератури, педагогічного спостереження, усного опитування, порівняння та абстрагування даних, було досягнуто мети дослідження. Проведене дослідження дало змогу припустити, щчо важливим правилом у роботі з молоддю є те, щз за будь-якого поєднання методів найбільш раціональним буде така їхня послідовність: роз'яснення, доведення, показ, практичне виконання вправи (тренування) з обов'язковим інструктажем (об'єм і величина навантаження). Така послідовність дасть змогу планомірно, залежно від індивідуальних особливостей фізичного розвитку кожного учня, студента, спортсмена формувати в нього позитивні навички до постійного самовдосконалення засобами фізичної культури і спорту. Під час проведення експерименту активний інтерес і позитивну привичку до системних занять фізичними вправами сформували $45 \%$ студентів та $38 \%$ учнів загального закладу освіти.

Ключові слова: фізична активність, спорт, методика, саморозвиток, молодь, виховання, навчання.

Проведення реформ у закладах освіти України вимагає, щоб у вихованні здорової, всебічно та гармонійно розвиненої молоді, яка буде повноправним членом суспільства та достойною зміною, важливе місце відводилось фізичній культурі і спорту. 